\title{
Article \\ Chromium Distribution, Leachability and Speciation in a Chrome Plating Site
}

\author{
Jiacong Sun ${ }^{1,2}$, Yating Luo ${ }^{1,2}$, Jien Ye ${ }^{1,2}$, Chunhui Li ${ }^{1,2}$ and Jiyan Shi ${ }^{1,2, *}$ \\ 1 Department of Environmental Engineering, College of Environmental and Resource Sciences, \\ Zhejiang University, Hangzhou 310058, China; wssjc111@126.com (J.S.); luoyating@zju.edu.cn (Y.L.); \\ yejien@zju.edu.cn (J.Y.);0619365@zju.edu.cn (C.L.) \\ 2 MOE Key Laboratory of Environment Remediation and Ecological Health, College of Environmental \& \\ Resource Science, Zhejiang University, Hangzhou 310058, China \\ * Correspondence: shijiyan@zju.edu.cn; Tel.: +86-571-8898-2019
}

check for updates

Citation: Sun, J.; Luo, Y.; Ye, J.; Li, C.; Shi, J. Chromium Distribution, Leachability and Speciation in a Chrome Plating Site. Processes 2022 10, 142. https://doi.org/10.3390/ pr10010142

Academic Editors: Guining Lu, Zenghui Diao and Kaibo Huang

Received: 17 November 2021

Accepted: 5 January 2022

Published: 10 January 2022

Publisher's Note: MDPI stays neutral with regard to jurisdictional claims in published maps and institutional affiliations.

Copyright: (C) 2022 by the authors. Licensee MDPI, Basel, Switzerland. This article is an open access article distributed under the terms and conditions of the Creative Commons Attribution (CC BY) license (https:// creativecommons.org/licenses/by/ $4.0 /)$.

\begin{abstract}
Hexavalent chromium (Cr(VI)) waste produced by chrome plating activities pollutes the surrounding environment and harms human health. However, information about the chromium $(\mathrm{Cr})$ pollution characteristics of actual electroplating sites is still lacking. In this study, the concentration, leachability and speciation of $\mathrm{Cr}$ in soils from a typical chrome plating site were analyzed. Our results showed that this site was severely contaminated by $\mathrm{Cr}(7.2$ to $7735.2 \mathrm{mg} / \mathrm{kg})$ and $\mathrm{Cr}(\mathrm{VI})$ reached the mean concentration of $138.7 \mathrm{mg} / \mathrm{kg}$. The spatial distribution of $\mathrm{Cr}(\mathrm{VI})$ was related to the plating processes. Chrome plating and sewage treatment areas could be considered as the hot spots of contaminated sites. The vertical distribution of $\mathrm{Cr}(\mathrm{VI})$ was mainly affected by soil properties, where the loam layer retained and reduced a large amount of $\mathrm{Cr}(\mathrm{VI})$ due to its high content of iron minerals and finer particle fractions. Additionally, the chemical extraction results showed that $\mathrm{Cr}$ was mainly in non-residual fractions and the existence of $\mathrm{Cr}(\mathrm{VI})$ led to a high leaching toxicity based on the toxicity characteristic leaching procedure (TCLP) results. Moreover, X-ray photoelectron spectroscopy (XPS) results revealed the speciation of $\mathrm{Cr}$ in the long-term contaminated soils. A large amount of $\mathrm{Cr}(\mathrm{VI})$ was reduced into $\mathrm{Cr}(\mathrm{III})$ and mainly existed as $\mathrm{Cr}(\mathrm{OH})_{3}$ and $\mathrm{Cr}_{2} \mathrm{O}_{3}$. Furthermore, $\mathrm{Cr}(\mathrm{VI})$ tended to precipitate as $\mathrm{CaCrO}_{4}$ and persisted in soils. Therefore, it is necessary to find appropriate strategies to remediate these contaminated soils. Overall, these findings strengthen our understanding of $\mathrm{Cr}(\mathrm{VI})$ behaviors and lay a foundation for the future pollution investigation, ecological remediation and risk assessment of sites contaminated by electroplating.
\end{abstract}

Keywords: hexavalent chromium; chrome plating site; pollution distribution; leachability; speciation

\section{Introduction}

Chromium $(\mathrm{Cr})$ is a common element in nature, which mainly comes from natural geologic and anthropogenic sources [1,2]. Serpentine soils are considered as the most important natural source of $\mathrm{Cr}$ [3]. In non-serpentine soils, the high $\mathrm{Cr}$ concentration is mainly attributed to anthropogenic activities, such as electroplating, steel and automobile manufacturing, leather tanning and wood preservation [4-6]. The oxidation states of $\mathrm{Cr}$ range from divalent $\mathrm{Cr}(\mathrm{II})$ to hexavalent $\mathrm{Cr}(\mathrm{VI})$, but the common forms in soil are $\mathrm{Cr}(\mathrm{VI})$ and trivalent $\mathrm{Cr}(\mathrm{III})[7,8]$. These states exhibit different chemical reactivities and toxicities $[9,10]$. $\mathrm{Cr}(\mathrm{III})$ is dominant in reducing conditions, has a low solubility and prefers to strongly sorb onto reducing substances $[2,6]$. $\mathrm{Cr}(\mathrm{VI})$ is highly mobile in soil and it mainly exists as oxyanions, such as $\mathrm{CrO}_{4}{ }^{2-}, \mathrm{HCrO}_{4}{ }^{-}$and $\mathrm{Cr}_{2} \mathrm{O}_{7}{ }^{2-}$ [11]. Due to its mutagenicity, carcinogenicity and teratogenic effects, $\mathrm{Cr}(\mathrm{VI})$ has been listed as one of the priority control pollutants by many countries and organizations [12]. Chromate, the main form of $\mathrm{Cr}(\mathrm{VI})$ compound, is commonly used in the electroplating industry [2,3]. Waste containing $\mathrm{Cr}(\mathrm{VI})$ is discharged from electroplating activities, especially chrome plating processes, which results in serious soil contamination $[13,14]$. 
With rapid industrialization, the electroplating industry has developed tremendously and there are more than 20,000 chrome plating process parks and workshops in China [15]. A growing number of studies have focused on the sources, compositions and pollution degrees of contaminated soils near electroplating plants [16-18]. Previous studies reported that the soil contaminated by electroplating had the characteristics of polymetallic pollution, of which $\mathrm{Cr}$ pollution was the most significant $[2,16]$. The $\mathrm{Cr}$ pollution level was relevant to the distance from and number of surrounding electroplating plants, as reported by Lin et al. [19] and Xiao et al. [16]. Electroplating activities can pollute the surrounding soil in many ways, including the leaking of plating solution, discharging of wastewater and stacking of electroplating sludge [16,20]. Additionally, contaminated soil generally has significant $\mathrm{Cr}(\mathrm{VI})$ concentrations with high carcinogenic risks [21,22]. Due to its high mobility, $\mathrm{Cr}(\mathrm{VI})$ can migrate into unsaturated zones and even be transported into groundwater, resulting in severe environmental pollution $[5,23]$. However, most previous studies have just focused on the $\mathrm{Cr}$ concentration in topsoil and have paid little attention to $\mathrm{Cr}(\mathrm{VI})$ and its vertical migration characteristics. Limited by time and space scale, it is difficult to accurately simulate the vertical migration of $\mathrm{Cr}(\mathrm{VI})$ in soil under laboratory conditions. Additionally, in situ remediation strategies have been largely performed in contaminated soil and the premise of this study is to determine the migration range of pollutants [24]. Therefore, it is necessary to study the vertical distribution of $\mathrm{Cr}(\mathrm{VI})$ in an actual electroplating site in order to clarify the migration characteristics of $\mathrm{Cr}(\mathrm{VI})$, which is of utmost importance to pollution remediation.

The chemical speciation of $\mathrm{Cr}$ is important for evaluating the leachability and environmental risk linked with $\mathrm{Cr}$ contaminated soil $[1,25,26]$. Species transformation often occurs during $\mathrm{Cr}(\mathrm{VI})$ migration, which is complicated in natural soil environments $[27,28]$. Soil properties, such as $\mathrm{pH}$, particle size, organic matter and clay minerals, can influence the geochemical behaviors of $\mathrm{Cr}$ by controlling its speciation [29-31]. Generally, $\mathrm{Cr}$ (VI) is considered to be available because it usually sorbs to oxide surfaces, predominantly as the outer-sphere complexes or weak inner-sphere complexes in soil [31,32]. Most $\mathrm{Cr}(\mathrm{VI})$ is commonly reduced by reducing substances (e.g., clay minerals, organic matter, microorganisms) and converted into less mobile and toxic $\mathrm{Cr}(\mathrm{III})$ in soil $[33,34]$. However, $\mathrm{Cr}(\mathrm{VI})$ can also be distributed in stable fraction via precipitation and the recrystallization of soil [35,36]. Identifying the speciation of chromium in contaminated soil is a prerequisite for pollution remediation and risk assessment [35,37]. To the best of our knowledge, the speciation characteristics of $\mathrm{Cr}$ in actual soils contaminated by electroplating have not been studied in depth.

Various industries need chrome metal coatings to prevent corrosion and enhance physical properties [21,38]. The manufacturing processes of chrome plating are diverse and thereby make the soil pollution conditions more complicated. High-concentration chromic acid waste liquid is the main industrial waste from electroplating, which is different from other chromium pollution industries, such as chromium salt production and leather making, and which may cause the soil pollution to be different from other industrial sites in terms of availability and speciation. In this study, $\mathrm{Cr}$ contaminated soils from a typical abandoned electroplating site were collected in order to: (i) determine the concentration and distribution characteristics of $\mathrm{Cr}_{\mathrm{T}}$ and $\mathrm{Cr}(\mathrm{VI})$ in the soil; (ii) assess the leachability and environmental risk of $\mathrm{Cr}$ in contaminated soil; and (iii) identify the speciation characteristics of $\mathrm{Cr}$ in contaminated soil. These results will help us to understand the geochemical behaviors of $\mathrm{Cr}(\mathrm{VI})$ in actual contaminated soils and also provide scientific information for risk assessment and pollution remediation.

\section{Materials and Methods}

\subsection{Site Description}

The study site is a chrome plating site located in an urban area of Hebei Province, with an area of $820.14 \mathrm{~m}^{2}$ (Figure 1A). This area is covered with quaternary sediments and the soil is mainly loess. This electroplating site began operation in 2005 and closed 
in 2015 and contained three workshops: an electroplating workshop; an electroplating laboratory; and a post-treatment workshop. The electroplating workshop was mainly used for hard chromium plating, decorative chromium plating and zinc plating. A small electroplating sewage tank of $8 \mathrm{~m}$ in length and $4 \mathrm{~m}$ in width also existed in this workshop. The preparation and testing of the plating solution were carried out in the electroplating laboratory. The post-plating treatment workshop was used for drying, packaging and storing raw materials. According to our previous site survey, the chromium pollution of soils in this area is obvious and the soil is alkaline, in which $\mathrm{Cr}(\mathrm{VI})$ exhibits a strong migration ability and high ecological risk [22,39].
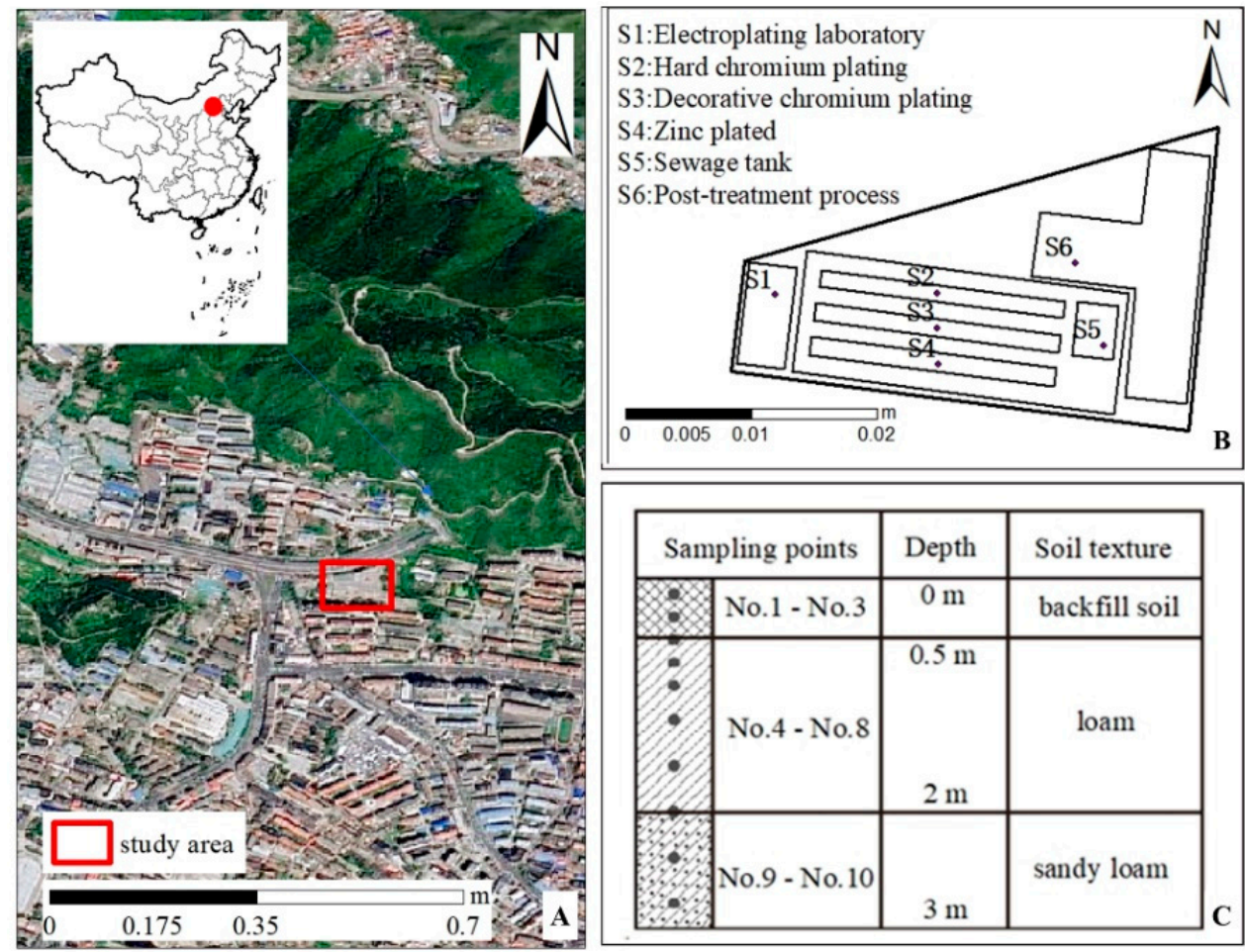

Figure 1. The satellite image of study area (A) and the sketch maps of sampling points $(\mathbf{B}, \mathbf{C})$.

\subsection{Sample Pretreatment}

The soil sampling points in this study were set at six different electroplating process sections: the electroplating laboratory (S1); hard chromium plating (S2); decorative chromium plating (S3); zinc plating (S4); the sewage tank (S5); and the post-treatment process (S6) (Figure 1B). Based on the preliminary investigation, the soil was sampled at different equidistant points. As the soil in the top layer $(0-1 \mathrm{~m})$ was usually heavily polluted, the sampling interval was $0.2 \mathrm{~m}$. In deeper soil, the chromium pollution might have abated, so the sampling interval correspondingly increased to $0.4 \mathrm{~m}$ (Figure 1C). Similar sampling methods have been used in previous studies [23]. The groundwater was buried below $60 \mathrm{~m}$ and was not found within our sampling depth range. All these soil samples were sealed in polyethylene plastic bags, stored in the dark and placed in a $4{ }^{\circ} \mathrm{C}$ refrigerator for subsequent analysis. The sample collection, storage and transportation were carried out in accordance with the Technical Guidelines for Site Environmental Investigation in China (HJ 25.1-2014). Stones, plant tissues and other dopants present in the soil samples were discarded before air-drying. After proper drying, all samples were crushed, homogenized and sieved through a $2 \mathrm{~mm}$ sieve, and then prepared for further analysis.

\subsection{Soil Characterization}

A series of physical and chemical properties of the soil was measured. Soil $\mathrm{pH}$ was measured in a 1:2.5 soil:water $(w / v)$ solution using a $\mathrm{pH}$ meter after $30 \mathrm{~min}$ of shaking. 
Organic matter content was determined by the ignition loss method. Particle size analysis was determined using the pipette method and classified according to the USDA soil classification. Thermogravimetric analysis was conducted to determine the concentration of $\mathrm{CaCO}_{3}$ in the soils using a thermogravimetric (TG, 209F3, Netsch, Germany). The mineralogical composition was determined by X-ray diffraction (XRD, D8 Advance, Bruker, Germany). According to the soil textural triangle [39], loam and sandy loam were the major textures of the soil, which were covered with a $0.5-\mathrm{m}$ thick backfill soil layer. Detailed soil characteristics can be found in Table 1 . The backfill soil contained construction waste and large-grain gravel, etc. The loam was mainly composed of fine-grained silt and had poor permeability. At the bottom, there were some large particles in the sandy loam, so its permeability was better than the loam layer.

After grinding the soil samples through a 100-mesh screen, uniform soil powders were obtained for heavy metal content and chemical speciation analysis. $\mathrm{The} \mathrm{Cr}(\mathrm{VI})$ in the soil was extracted by alkaline digestion according to the US Environmental Protection Agency Method (EPA 3060A). After digestion, the extracted solution was filtered through a $0.22-\mu \mathrm{m}$ filter membrane and the $\mathrm{Cr}(\mathrm{VI})$ concentration was determined by the by the 1.5 diphenylcarbazide spectrophotometric method using a UV-Vis spectrum (EPA Method 7196A). A given amount (0.2 g) of the soil samples was digested with $\mathrm{HNO}_{3} / \mathrm{HF} / \mathrm{HCLO}_{4}$ $(7: 5: 5, v / v / v)[40]$. The total $\mathrm{Cr}, \mathrm{Zn}$ and $\mathrm{Cu}$ in the digestion solution were analyzed by a flame atomic absorption spectrophotometer (FAAS, PinAAcle 900F, PerkinElmer, Singapore) after filtration and dilution. The mobility and leachability of $\mathrm{Cr}(\mathrm{VI})$ in the soil samples were determined using TCLP analyses (USEPA Method 1311).

\subsection{Chemical Fraction and Speciation Analyses of $\mathrm{Cr}$}

We conducted $\mathrm{Cr}$ chemical fractions analysis on representative soils which came from different soil layers of three polluted points. Heavy metals in the soil were classified into the following five fractions using sequential extraction method carried out by Tessier et al. [41]: exchangeable fraction (F1); carbonate bound fraction (F2); Fe-Mn oxide bound fraction (F3); organic matter bound fraction (F4); and residual fraction (F5). A two-step sequential extraction method was used for the fractionation analysis of mobile $\mathrm{Cr}(\mathrm{VI})$ and immobile $\mathrm{Cr}(\mathrm{VI})$ in the soil [35,42]. The total concentration of the recovered $\mathrm{Cr}$ and $\mathrm{Cr}(\mathrm{VI})$ ranged from $91.8 \%$ to $118.2 \%$ and $83.5 \%$ to $103.6 \%$, respectively, suggesting that these sequential extraction results were reliable. The chemical state of $\mathrm{Cr}$ was identified using X-ray photoelectron spectroscopy (XPS, Thermo Scientific K-Alpha, Waltham, MA, USA).

\subsection{Quality Assurance (QA) and Quality Control (QC)}

All reagents used in this study were analytical grade and purchased from Sinopharm Chemical Reagent Co., Ltd. Deionized water was used throughout the experiments. QA and QC were implemented using duplicates and regent blanks. All analyses were performed in triplicate under the same conditions and the standard deviations were less than $5.0 \%$. We chose the optimum detection wavelength for elements when using atomic adsorption spectroscopy. The linearity was kept strong, with correlation coefficients $>99.9 \%$, by preparing calibration curves with a series of concentrations $(0.5 \mathrm{mg} / \mathrm{L}-4 \mathrm{mg} / \mathrm{L})$. Additionally, the accuracy of the analytical procedure was checked by certified material GBW07449.

\subsection{Statistical Analysis and Calculation}

All statistical analyses were conducted with the IMB SPSS Statistics Ver 20.0 software and Excel 2010. The figures were generated using ArcGIS 10.5 and Origin Ver 9.0. The geo-accumulation index $\left(\mathrm{I}_{\text {geo }}\right)$ is a commonly used method to assess the severity of heavy metal contamination in soils $[28,43,44]$. This method was introduced by Muller [45] and can be defined as follows:

$$
\mathrm{I}_{\text {geo }}=\log _{2}\left[\mathrm{C}_{\mathrm{n}} /\left(1.5 \times \mathrm{B}_{\mathrm{n}}\right)\right] \text {, }
$$

where $\mathrm{I}_{\text {geo }}$ is the geo-accumulation index (soil contamination severity index) and $\mathrm{Cn}$ is the heavy metal content in soil. Bn is the average concentration of element in the 
background rock sample, and we selected the local soil chromium content background value of $61.0 \mathrm{mg} / \mathrm{kg}$. Pollution levels on the basis of the $\mathrm{I}_{\text {geo }}$ can be classified as (I) practically unpolluted $(\leq 0)$, (II) unpolluted to moderately polluted $(0-1)$, (III) moderately polluted (1-2), (IV) moderately to heavily polluted (2-3), (V) heavily polluted (3-4), (VI) heavily to extremely polluted (4-5) and (VII) extremely polluted $(>5)$.

\section{Results and Discussion}

\subsection{Total Concentration and Oxidation State of Chromium in Soils}

The $\mathrm{Cr}_{\mathrm{T}}$ and $\mathrm{Cr}(\mathrm{VI})$ contents of the soil samples are shown in Table 1. The results showed that the $\mathrm{Cr}_{\mathrm{T}}$ concentrations of the soil ranged from 7.2 to $7735.2 \mathrm{mg} / \mathrm{kg}$. The mean concentration of $\mathrm{Cr}_{\mathrm{T}}$ in the soil was $948.2 \mathrm{mg} / \mathrm{kg}$, which was more than 15 times higher than the background values for soils in China [46]. The pollution degree of this electroplating site appeared to be serious. The $I_{\text {geo }}$ value ranged from 0.06 to 6.23 , and six samples even reached the extremely polluted level ( $\mathrm{I}_{\text {geo }}>5$ ) (Tables S1-S3). Chromic acid solution was the raw material used in the chrome plating activities and it could easily enter nearby soil by escaping, emitting, dripping and leaking during the production processes [21,47]. In this area, the average $\mathrm{Cr}(\mathrm{VI})$ concentration was $138.74 \mathrm{mg} / \mathrm{kg}$, which significantly exceeded the China Environmental Quality Standards for Soils [48].

Comparisons with previous studies reveal that the $\mathrm{Cr}(\mathrm{VI})$ pollution caused by electroplating activities was lighter than that of chromite ore processing residue $(4575-6530 \mathrm{mg} / \mathrm{kg}$ ) [49] and chromate production $(3120-7934 \mathrm{mg} / \mathrm{kg}$ ) [50], but it was significantly more serious than that of leather tanning (51.5-144.2 mg/ $\mathrm{kg}$ ) [51] and wood preservation (ND$-70.7 \mathrm{mg} / \mathrm{kg}$ ) [52]. These results illustrate that electroplating activities caused severe chromium pollution in the soil and might have affected the health of surrounding humans. In addition, the relatively high standard deviation values reflect that the chromium concentration varied among the different sampling points and soil depths.

Table 1. The basic statistical parameters of the soil chromium contents in the electroplating site.

\begin{tabular}{|c|c|c|c|c|c|c|c|c|c|c|c|c|c|}
\hline \multirow{2}{*}{$\begin{array}{l}\text { Sampling } \\
\text { Points }\end{array}$} & S1 & S2 & S3 & S4 & S5 & S6 & S1 & S2 & S3 & S4 & S5 & S6 & \multirow{2}{*}{ References } \\
\hline & \multicolumn{6}{|c|}{ Total Cr (mg/kg) } & \multicolumn{6}{|c|}{$\mathrm{Cr}(\mathrm{VI})(\mathrm{mg} / \mathrm{kg})$} & \\
\hline Mean & 18.0 & 98.4 & 4081.2 & 19.2 & 523.0 & 20.9 & 0.3 & 29.5 & 763.7 & 0.3 & 38.5 & 0.7 & (In this study) \\
\hline Median & 12.9 & 87.4 & 3855.9 & 15.0 & 114.5 & 21.1 & 0.1 & 25.0 & 356.6 & 0.3 & 20.9 & 0.2 & \\
\hline Min & 7.2 & 42.1 & 33.4 & 8.2 & 42.2 & ND & ND & 5.2 & 32.4 & ND & 6.5 & ND & \\
\hline Max & 33.6 & 164.1 & 7735.2 & 39.5 & 3178.2 & 26.9 & 1.1 & 80.1 & 2298.2 & 1.0 & 163.5 & 2.0 & \\
\hline StDev ${ }^{1}$ & 10.1 & 42.8 & 3100.6 & 13.2 & 980.4 & 4.1 & 0.5 & 23.9 & 880.9 & 0.3 & 49.0 & 0.8 & \\
\hline OSR $(\%)^{2}$ & - & 80.0 & 80.0 & 10.0 & 70.0 & - & - & 50.0 & 100.0 & - & 30.0 & - & \\
\hline BVSC $^{3}$ & \multicolumn{6}{|c|}{61.0} & \multicolumn{6}{|c|}{-} & [46] \\
\hline SRSD $^{4}$ & \multicolumn{6}{|c|}{-} & \multicolumn{6}{|c|}{30.0} & [48] \\
\hline
\end{tabular}

${ }^{1}$ StDev: Standard deviation. ${ }^{2}$ OSR: Over-standard rate. ${ }^{3}$ BVSC: Background values for soils in China. ${ }^{4}$ SRSD: Soil environmental quality risk control standard for the soil contamination of development land (GB36600-2018).

Detailed soil characteristics can be found in Table 2. According to the soil textural triangle [53], loam and sandy loam were the major textures of the soil, which were covered with a $0.5-\mathrm{m}$ thick backfill soil layer. The backfill soil contained construction waste and large-grain gravel, etc. The loam was mainly composed of fine-grained silt and had poor permeability. At the bottom, there were some large particles in the sandy loam, so its permeability was better than the loam layer. Additionally, the backfill soil and the loam layer contained more iron minerals, based on the XRD results shown in Figure S1. The soil in this area was alkaline and the $\mathrm{pH}>8.0$ at all soil layers, with significant $\mathrm{CaCO}_{3}$ levels present. $\mathrm{CaCO}_{3}$ could increase the soil $\mathrm{pH}$ and reduce the availability of heavy metals [54]. Such an alkaline condition was conducive to the transport of $\mathrm{Cr}(\mathrm{VI})$, as the adsorption and reduction processes were inhibited [55]. However, an obvious decrease in soil $\mathrm{pH}$ values can be observed and shows a significant negative relationship with $\mathrm{Cr}(\mathrm{VI})$ concentration $(\mathrm{r}=-0.817, p<0.01)$ (Tables S1-S3). This phenomenon was mainly attributed to the acid electroplating effluent, and similar results were also found by Xiao [16] and Bedbabis [56]. 
The acidification tended to cause more positive charge on the soil particle surface, thereby enhancing the $\mathrm{Cr}(\mathrm{VI})$ retention, as reported in other studies $[39,57]$. Furthermore, the $\mathrm{CaCO}_{3}$ content also decreased with the $\mathrm{Cr}$ accumulation, especially at the most polluted sampling point S3 (Tables S1-S3). Therefore, electroplating activities also caused the acidification of the soil and the loss of $\mathrm{CaCO}_{3}$, which might have affected $\mathrm{Cr}$ behaviors in the soil.

Table 2. The physicochemical properties of the soil layers at this chrome plating site.

\begin{tabular}{|c|c|c|c|c|c|c|c|c|}
\hline \multirow{2}{*}{ Soil Layers } & Depth & & Particles (\%) & & $\mathrm{pH}$ & $\mathrm{OM}$ & $\mathrm{CaCO}_{3}$ & $\begin{array}{c}\text { Permeability } \\
\text { Coefficient }\end{array}$ \\
\hline & $\mathbf{m}$ & $2 \sim 0.05 \mathrm{~mm}$ & $0.05 \sim 0.002 \mathrm{~mm}$ & $<0.002 \mathrm{~mm}$ & - & $\%$ & $\%$ & $\mathrm{~cm} / \mathrm{s}$ \\
\hline Backfill soil & $0 \sim 0.5$ & - & - & - & 8.56 & 0.46 & 9.83 & - \\
\hline Loam & $0.5 \sim 2$ & $33.78 \%$ & $44.04 \%$ & $22.18 \%$ & 8.43 & 0.34 & 8.62 & $8.59 \times 10^{-7}$ \\
\hline Sandy loam & $>2$ & $54.01 \%$ & $30.75 \%$ & $15.25 \%$ & 8.65 & 0.45 & 7.00 & $1.56 \times 10^{-4}$ \\
\hline
\end{tabular}

To sum up, electroplating activities caused serious soil chromium pollution and changes in soil properties due to the insufficient anti-seepage measures. Although most of the $\mathrm{Cr}(\mathrm{VI})$ had been reduced into $\mathrm{Cr}(\mathrm{III})(>80 \%)$, the proportion of $\mathrm{Cr}(\mathrm{VI})$ to $\mathrm{Cr}_{\mathrm{T}}$ at this site was larger than that at other chromium contaminated sites [16,21,51]. The toxicity and environmental risks cannot be neglected. Furthermore, the $\mathrm{Cr}(\mathrm{VI})$ contents varied in different soil samples. Therefore, investigating the distribution of $\mathrm{Cr}(\mathrm{VI})$ in both spatial and vertical aspects is essential for future remediation and risk control.

\subsection{Spatial and Vertical Distribution Characteristics of Chromium in Soils}

Figure 2 compares the concentrations of $\mathrm{Cr}_{\mathrm{T}}$ and $\mathrm{Cr}(\mathrm{VI})$ in the soils from the different sampling points. Relatively high $\mathrm{Cr}(\mathrm{VI})$ was observed in the electroplating workshop, where the $\mathrm{Cr}(\mathrm{VI})$ values in the soils of hard chromium plating $(\mathrm{HCP})$, decorative chromium plating (DCP) and sewage tank (ST) ranged from 5.2 to $80.1 \mathrm{mg} / \mathrm{kg}$ (S2), from 32.4 to $2298.2 \mathrm{mg} / \mathrm{kg}$ (S3) and from 6.5 to $163.5 \mathrm{mg} / \mathrm{kg}$ (S5), respectively (Figure 2a). In contrast, $\mathrm{Cr}(\mathrm{VI})$ occurred at much lower concentrations in the soils from S1, S4 and S6. $\mathrm{Cr}_{\mathrm{T}}$ presented similar characteristics as $\mathrm{Cr}(\mathrm{VI})$ in terms of distribution (Figure $2 \mathrm{~b}$ ). It was heterogeneously distributed in this contaminated area and concentrated in those processes that directly involved the use and collection of $\mathrm{Cr}(\mathrm{VI})$, as previous studies reported [58-60]. Contrasting with the two plating points S2 and S3, most of the $\mathrm{Cr}(\mathrm{VI})$ had been converted to $\mathrm{Cr}(\mathrm{III})$ before it leaked into the soil during the sewage treatment processes [61], therefore the $\mathrm{Cr}$ (III) species was dominant at S5. Additionally, obvious Zinc ( $\mathrm{Zn})$ and cooper $(\mathrm{Cu})$ concentrations were detected in the soils at S3, S4 and S5 (Figure 2c,d). Cu is usually used as the intermediate coating in DCP processes or/and as the metal matrix in Zinc plating processes $[62,63]$. The sewage tank collected all wastewater produced during the electroplating activities, so the nearby soil had polymetallic pollution characteristics. Therefore, the chromium distribution in an actual electroplating site was related to the specific manufacturing processes and was accompanied by the characteristics of polymetallic enrichment. The chrome plating and sewage treatment areas could be considered as the hot spots of the contaminated site.

The $\mathrm{Cr}_{\mathrm{T}}$ and $\mathrm{Cr}(\mathrm{VI})$ contents in the contaminated soils at various depths are shown in Figure 3. $\mathrm{Cr}(\mathrm{VI})$ could be still detected in the bottom samples at S2, S3 and S5 (80.1, 32.4 and $21.8 \mathrm{mg} / \mathrm{kg}$, respectively), indicating the deeper pollution range and higher vertical diffusion of $\mathrm{Cr}(\mathrm{VI})$ compared to other contaminated sites [21,49]. As for the vertical aspect, the soil chromium pollution was closely related to the soil layers. The pollutants firstly tended to concentrate in the surface layer of the backfill soil and then accumulate to a certain level, in line with previous site studies $[23,60,64]$. There was a certain degree of $\mathrm{Cr}$ (VI) accumulation within the loam layer (0.5-2 $\mathrm{m}$ in depth) and it even reached the highest concentration of $2298.2 \mathrm{mg} / \mathrm{kg}$ (Figure 3b). On the contrary, the $\mathrm{Cr}(\mathrm{VI})$ content 
in the sandy loam layer was much lower than the other two soil layers. Cr(III) occurred at various depths and exhibited similar distribution characteristics to $\mathrm{Cr}$ (VI) (Figure 3). Cr pollutants produced by electroplating were mainly in the $\mathrm{Cr}(\mathrm{VI})$ form, and the $\mathrm{Cr}$ (III) contents could reflect the reduction ability of the soil [34,39]. $\mathrm{Cr}(\mathrm{VI})$ accounted for $3.8 \%$ to $37.8 \%$ of the $\mathrm{Cr}_{\mathrm{T}}$ in the loam layer, while it was the dominant species and just a small proportion of $\mathrm{Cr}(\mathrm{VI})(<30 \%)$ reduced into $\mathrm{Cr}(\mathrm{III})$ in the sandy loam layer. It was indicated that the reduction of $\mathrm{Cr}(\mathrm{VI})$ was also in various different soil layers. It was concluded that the vertical distribution of $\mathrm{Cr}$ and its specie interconversion was strongly influenced by soil properties.
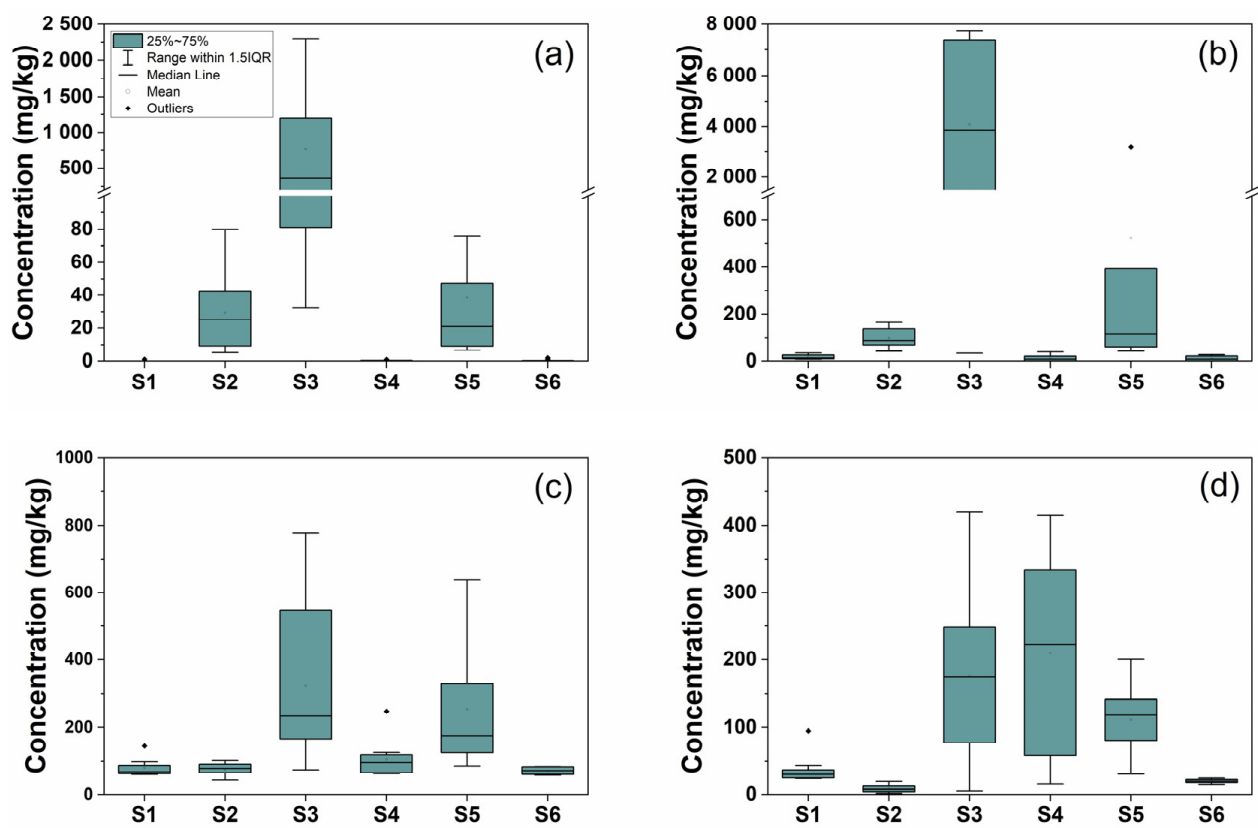

Figure 2. The concentrations of heavy metals in the soils at the different sampling points. (a) $\mathrm{Cr}(\mathrm{VI})$, (b) Total Cr, (c) Cu and (d) Zn.

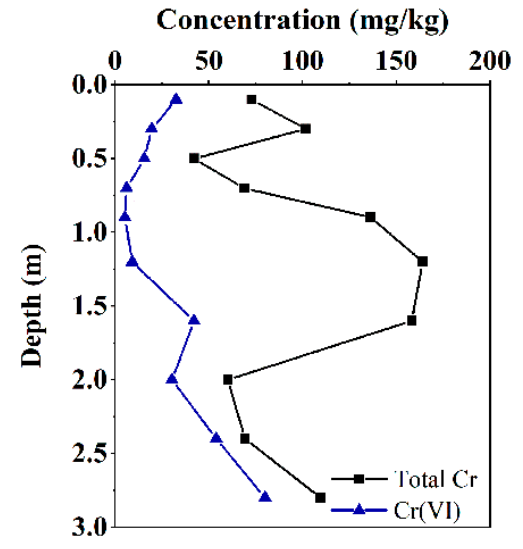

(a)

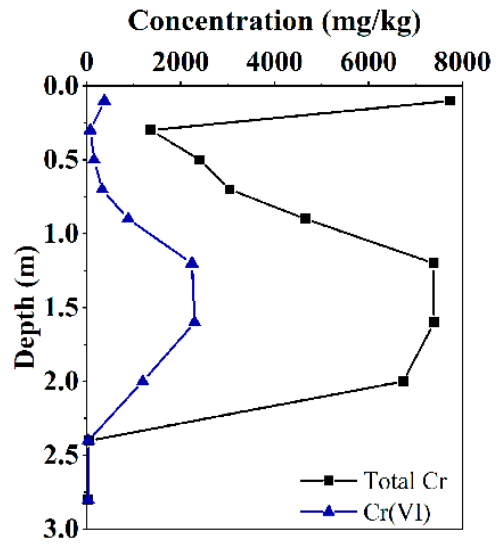

(b)

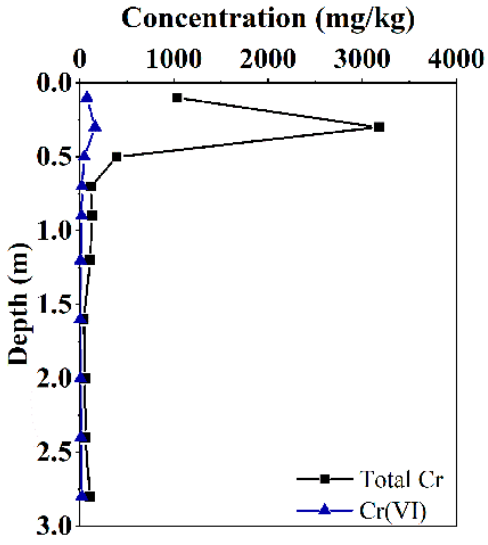

(c)

Figure 3. The vertical distribution of $\mathrm{CrT}$ and $\mathrm{Cr}(\mathrm{VI})$ in the soils at contaminated sampling point S2 (a), S3 (b) and S5 (c).

The loam layer made a great contribution to the retention and reduction of hexavalent chromium, as Figure 3 shows. It contained a relative proportion of clay fraction $(<2 \mu \mathrm{m})$, with a permeability coefficient of $8.6 \times 10^{-7} \mathrm{~cm} / \mathrm{s}$ (Table 2). During downward migration, $\mathrm{Cr}(\mathrm{VI})$ could be hindered and retained by this layer due to its low permeability, which had been demonstrated both in a laboratory experiment [65] and in site surveys [66]. Moreover, 
the smaller sized particles had a larger cation exchange capacity, specific surface areas and clay component contents, which resulted in its greater $\mathrm{Cr}$ adsorption ability [67,68]. On the contrary, larger and more coarse particles were found in the backfill soil and the sandy loam layer. $\mathrm{Cr}(\mathrm{VI})$ can easily migrate downward under the eluviation of groundwater. Thus, the soil texture determined the vertical distribution of the pollutants to a certain extent. In soil, the potential interconversion between $\mathrm{Cr}(\mathrm{III})$ and $\mathrm{Cr}(\mathrm{VI})$ was dependent on the content of reduction substances [1,42]. The backfill soil and loam layer contained more clay minerals, especially iron minerals (Figure S1), which were main storage sinks for $\mathrm{Cr}$, as well as main reducing agents contributing to the $\mathrm{Cr}(\mathrm{VI})$ transformation $[34,69]$. The content of soil organic matter, another main reduction substance, had relatively narrow gaps among these soil layers, so the effect of the organic matter on the difference between the soil layers was minimal. Furthermore, soil environmental variables, such as $\mathrm{pH}[6,55]$, redox potential (ORP) $[57,69]$ and metal stress [21,24], may affect chromium behaviors in soil. In this study, $\mathrm{pH}$ played a non-negligible role in $\mathrm{Cr}(\mathrm{VI})$ distribution. As discussed in the above section, the soil acidification might have exaggerated the $\mathrm{Cr}(\mathrm{VI})$ retention.

At S3 and S5, $\mathrm{Zn}$ and $\mathrm{Cu}$ were detected at various depths and their vertical distributions were similar to $\mathrm{Cr}$ (Figure S2). The Pearson correlation analysis (Figure 4) shows that there were positive correlations among the concentration of $\mathrm{Cr}, \mathrm{Zn}$ and $\mathrm{Cu}$ in the soil. The correlation coefficients found in the pairs of $\mathrm{Zn}-\mathrm{Cr}(\mathrm{VI})(\mathrm{r}=0.758, p<0.01)$ and $\mathrm{Cu}-\mathrm{Cr}(\mathrm{VI})$ $(\mathrm{r}=0.535, p<0.05)$ were positive, where $\mathrm{Zn}$ showed better affinity with $\mathrm{Cr}(\mathrm{VI})$ than $\mathrm{Cu}$. The coexisting heavy metals may promote or inhibit their adsorption in soil [70,71], which is closely related to the metal valence state, concentration, adsorption capacity and affinity in soil [70]. Some previous research reported that $\mathrm{Cu}$ could affect the adsorption and transformation of $\mathrm{Cr}(\mathrm{VI})$ in soil [70,71], while related studies on $\mathrm{Zn}$ are limited. It was concluded that the coexistence of multiple metals was an important characteristic affecting the $\mathrm{Cr}$ distribution in the soil, and the interaction mechanism is worthy of further investigation.

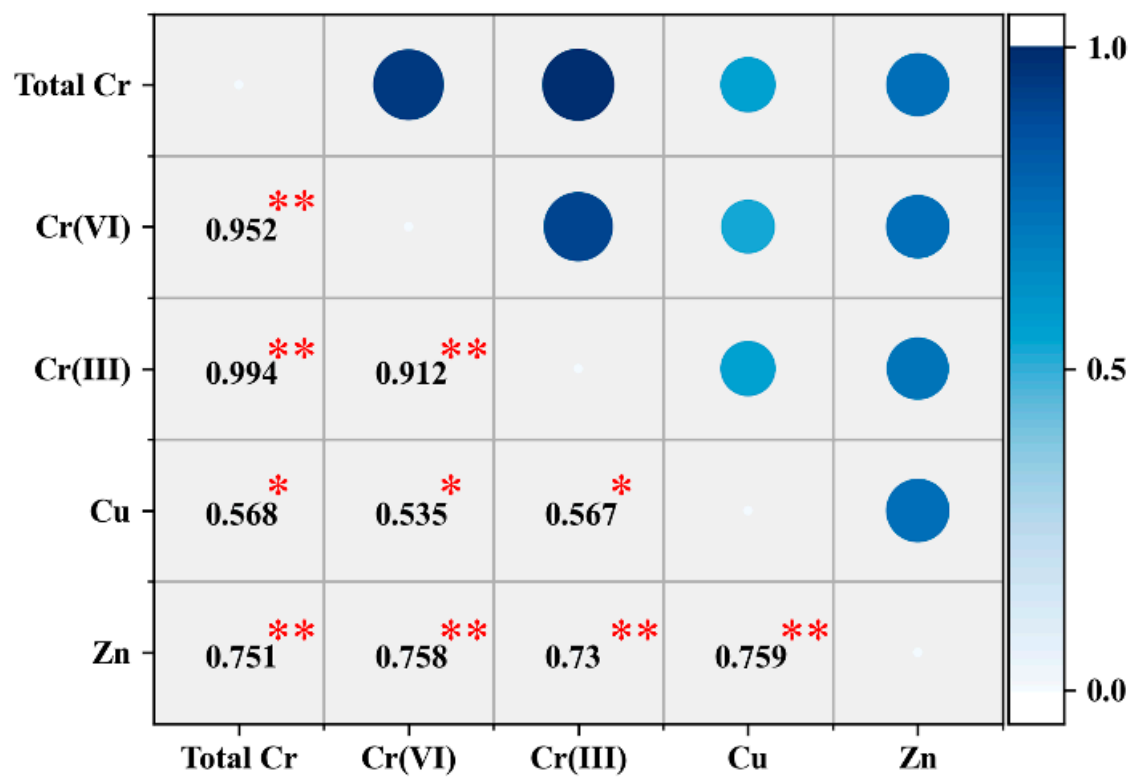

Figure 4. The correlation matrix analysis of the heavy metals in the soils $\left({ }^{*}=p<0.05,{ }^{* *}=p<0.01\right)$.

\subsection{Leachability Characteristics and Mobility of Chromium in Soils}

Besides the total chromium content, more information about heavy metal availability is necessary in order to estimate the potential risk. The toxicity characteristic leaching procedure (TCLP) has been widely used to evaluate the mobility of heavy metals in soil and to estimate their leachability and availability under acidic conditions (USEPA 1992). The Cr(VI) concentrations leached by TCLP were 0.2 to $58.9 \mathrm{mg} / \mathrm{L}$ (S2), 24.8 to $421.1 \mathrm{mg} / \mathrm{L}$ (S3) and 1.5 to $48.7 \mathrm{mg} / \mathrm{L}$ (S5), respectively (Figure 5b). The leaching concentrations of $\mathrm{Cr}_{\mathrm{T}}$ 
were 0.3 to $63.3 \mathrm{mg} / \mathrm{L}$ (S2), 26.6 to $430.2 \mathrm{mg} / \mathrm{L}$ (S3) and 1.9 to $58.8 \mathrm{mg} / \mathrm{L}$ (S5), respectively (Figure 5a). These results show that $\mathrm{Cr}(\mathrm{VI})$ accounted for a high proportion of the total leached $\mathrm{Cr}$, suggesting that $\mathrm{Cr}(\mathrm{VI})$ was the significant contributor to the pollution diffusion risk of the contaminated soil. Meanwhile, the availability of chromium at the DCP point (S3) was the highest because of the high $\mathrm{Cr}(\mathrm{VI})$ content in the soil. In addition, not only the $\mathrm{Cr}(\mathrm{VI})$ proportion of the total $\mathrm{Cr}$ but also the extracted rate of $\mathrm{Cr}(\mathrm{VI})$ (extracted $\mathrm{Cr}(\mathrm{VI}) /$ total $\mathrm{Cr}(\mathrm{VI})$ ) was the highest in the sandy loam layer. This means that $\mathrm{Cr}(\mathrm{VI})$ leached from contaminated soils has greater abilities to diffuse deeper in the bottom sandy loam layer. The leaching concentration of $\mathrm{Cr}(\mathrm{VI})$ in the 17 contaminated soil samples exceeded the USEPA regulatory limit of $5 \mathrm{mg} / \mathrm{L}$. Therefore, the contaminated soils in this electroplating site appeared to have a high $\mathrm{Cr}(\mathrm{VI})$ diffusion risk and can serve as a potential source of $\mathrm{Cr}(\mathrm{VI})$ for the surrounding environment.
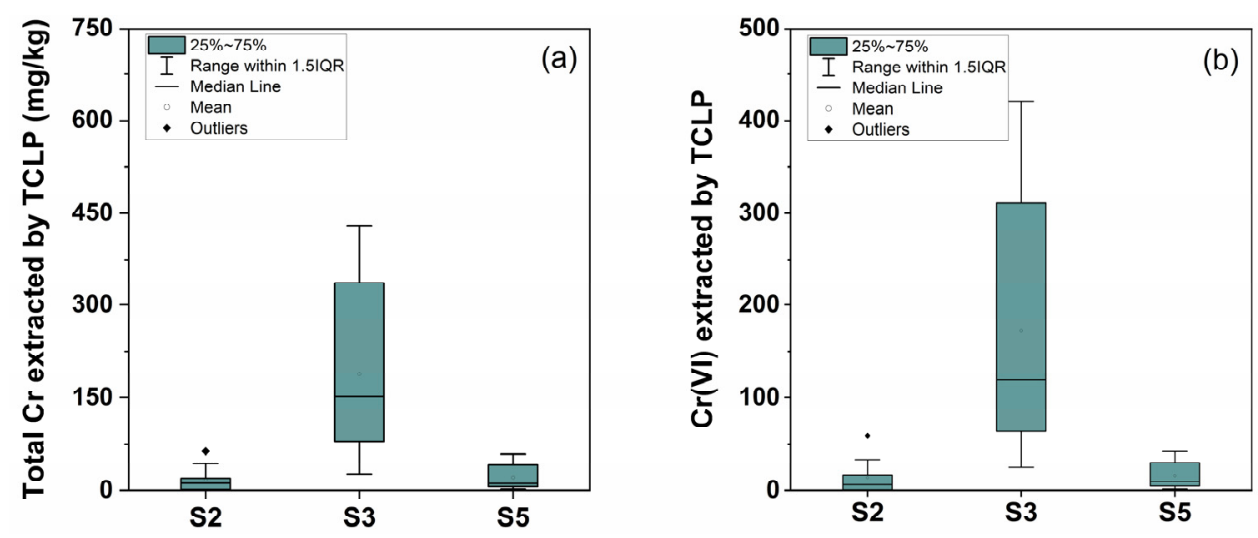

Figure 5. The contents of (a) total $\mathrm{Cr}$ and (b) Cr(VI) extracted by TCLP in contaminated soils at S2, S3 and S5.

We conducted sequential extraction to evaluate the mobility of $\mathrm{Cr}_{\mathrm{T}}$. The sequential extraction method divided the total heavy metal into five fractions: exchangeable fraction (F1); carbonate bound fraction (F2); Fe-Mn oxide bound fraction (F3); organic matter bound fraction (F4); and residual fraction (F5) (Figure 6). F5 was the most stable fraction and the relatively low proportion of F5 clearly indicated the higher mobile potential of $\mathrm{Cr}$ compared to other $\mathrm{Cr}$ contaminated sites [59,72]. F3 and F4 were the main fractions of $\mathrm{Cr}$ in the contaminated soils. Heavy metals in the fractions of F3 and F4 were unstable, and potentially mobile and bioavailable under certain environmental conditions [59,73]. F1 and F2 were considered as mobile fractions that can easily be released from the soil $[6,27]$. The percentage of $\mathrm{Cr}$ in the mobile portion (F1 and F2) was relatively high ( $>25 \%)$ in the sandy loam, which suggested a high diffusion risk in accordance with our TCLP results.

From the outset, $\mathrm{Cr}(\mathrm{VI})$ was the main pollutant and contributor to leaching toxicity. The results of the two-step sequential extraction show that mobile $\mathrm{Cr}(\mathrm{VI})$ accounted for only $24.2 \%$ to $38.3 \%$ of the total $\mathrm{Cr}(\mathrm{VI})$ in the backfill soil, $9.8 \%$ to $26.6 \%$ in the loam and $17.3 \%$ to $37.8 \%$ in the sandy loam, demonstrating that the majority of $\mathrm{Cr}(\mathrm{VI})$ in these soils was in the immobile fraction (Figure 6). $\mathrm{Cr}(\mathrm{VI})$ is toxic and highly mobile in soil [74], and while these results show that $\mathrm{Cr}(\mathrm{VI})$ was mainly distributed in a stable fraction, they were inconsistent with the hypothesis that $\mathrm{Cr}(\mathrm{VI})$ was easy to extract from soils $[26,57]$. The stable fraction of $\mathrm{Cr}(\mathrm{VI})$ in the long-term naturally contaminated soils has been reported and has attracted more attention [35,37]. Wisconsin et al. [75] found that only a small fraction $(<10 \%)$ of the total $\mathrm{Cr}(\mathrm{VI})$ was extracted with a phosphate buffer in soils polluted by electroplating. Therefore, immobilization is also an important fate of $\mathrm{Cr}(\mathrm{VI})$ in soils contaminated by electroplating. Comparing the $\mathrm{Cr}(\mathrm{VI})$ concentrations, $\mathrm{Cr}(\mathrm{VI})$ leached by TCLP was higher than that extracted by the phosphate buffer solution, indicating that $\mathrm{Cr}(\mathrm{VI})$ in this stable fraction could be gradually leaching soluble $\mathrm{Cr}(\mathrm{VI})$ into the surrounding soil. 
(a)
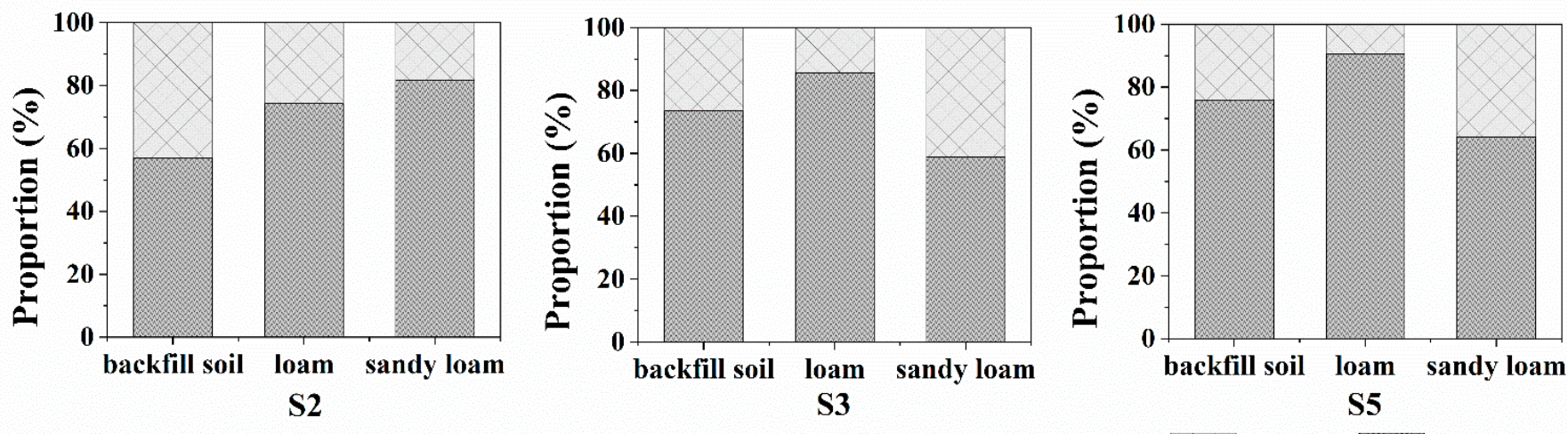

(b)
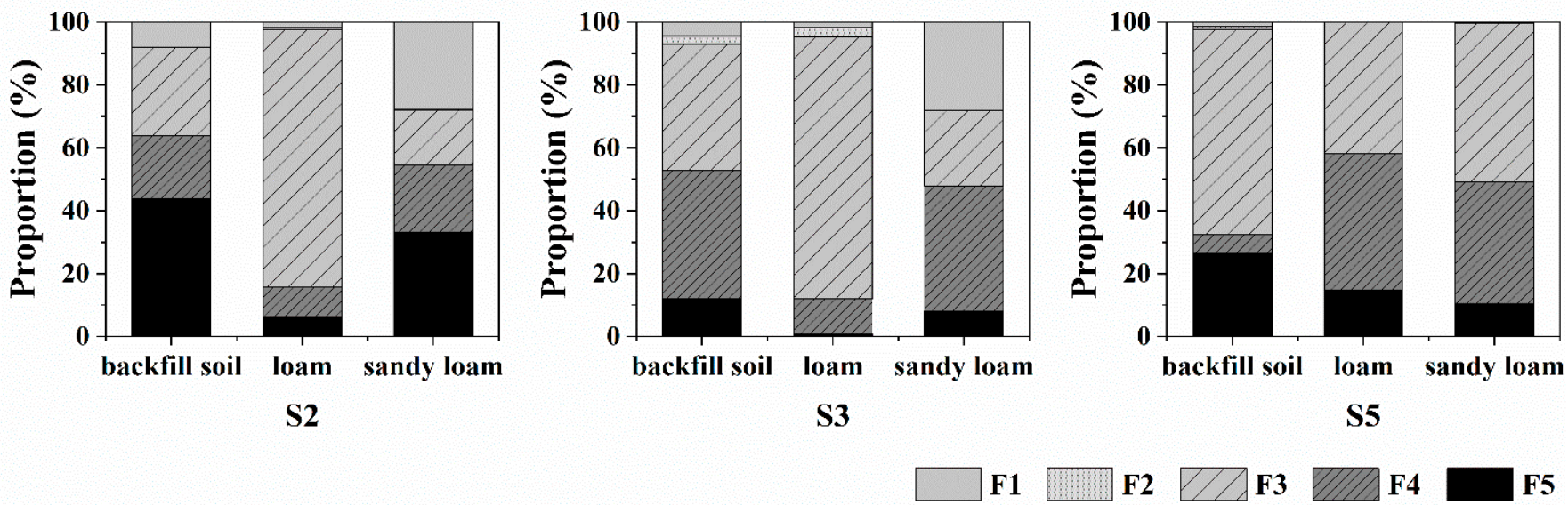

F4 F5

Figure 6. The chemical fractions of $\mathrm{Cr}(\mathrm{VI})(\mathbf{a})$ and total $\mathrm{Cr}(\mathbf{b})$ based on sequential extraction.

Overall, most of the $\mathrm{Cr}$ in the polluted soils of this electroplating site was present in the non-residual fraction and thus, had a greater risk of pollutant release and diffusion. $\mathrm{Cr}(\mathrm{VI})$ tended to be distributed in a stable fraction and be retained in soils. However, these stable fractions could also leak $\mathrm{Cr}(\mathrm{VI})$ and pollute surrounding areas into acidic environments.

\subsection{Speciation Characteristics of Chromium in Soils}

The speciation of heavy metals can demonstrate several important trends with respect to the mobility, release potentials and eco-toxicity of heavy metals $[59,76]$. Figure 7 displays the $\mathrm{Cr} 2 \mathrm{p}$ XPS spectra of the soil samples with a high $\mathrm{Cr}$ concentration. There were obvious Cr peaks in the spectrum and $\mathrm{Cr}(\mathrm{III})$ accounted for a large proportion of the total $\mathrm{Cr}$, which was consistent with our previous results. $\mathrm{Cr}(\mathrm{OH})_{3}$ was the most stable species of $\mathrm{Cr}(\mathrm{III})$ and it accounted for the largest proportion, supporting the low mobility of $\mathrm{Cr}(\mathrm{III})$ in the soil. $\mathrm{Cr}_{2} \mathrm{O}_{3}$ was the second $\mathrm{Cr}(\mathrm{III})$ species, and a small amount of $\mathrm{CrOOH}$ also occurred in soil. Previous studies demonstrated that $\mathrm{Cr}(\mathrm{III})$ derived from the $\mathrm{Cr}(\mathrm{VI})$ reduction generally form surface complexes near the surface of organic matter and iron oxide [77,78]. In this study, a high proportion of $\mathrm{Cr}$ was distributed in the F3 and F4 fractions, which was probably due to the $\mathrm{Cr}(\mathrm{VI})$ reduction (Figure 6). Zhao et al. [79] also confirmed that the majority of $\mathrm{Cr}(\mathrm{VI})$ was first reduced to $\mathrm{Cr}(\mathrm{III})$ in soils, resulting in the content of $\mathrm{F} 3$ and F4 with increased time. At S2 and S3, F3 was the dominant Cr fraction in the loam layer $(>80 \%)$, suggesting that $\mathrm{Fe}-\mathrm{Mn}$ oxides were the main carriers of $\mathrm{Cr}$ in the loam layer. This result was related to the higher iron mineral content in the loam layer (Figure S1), which could have contributed to $\mathrm{Cr}$ reduction and accumulation in the loam layer. 

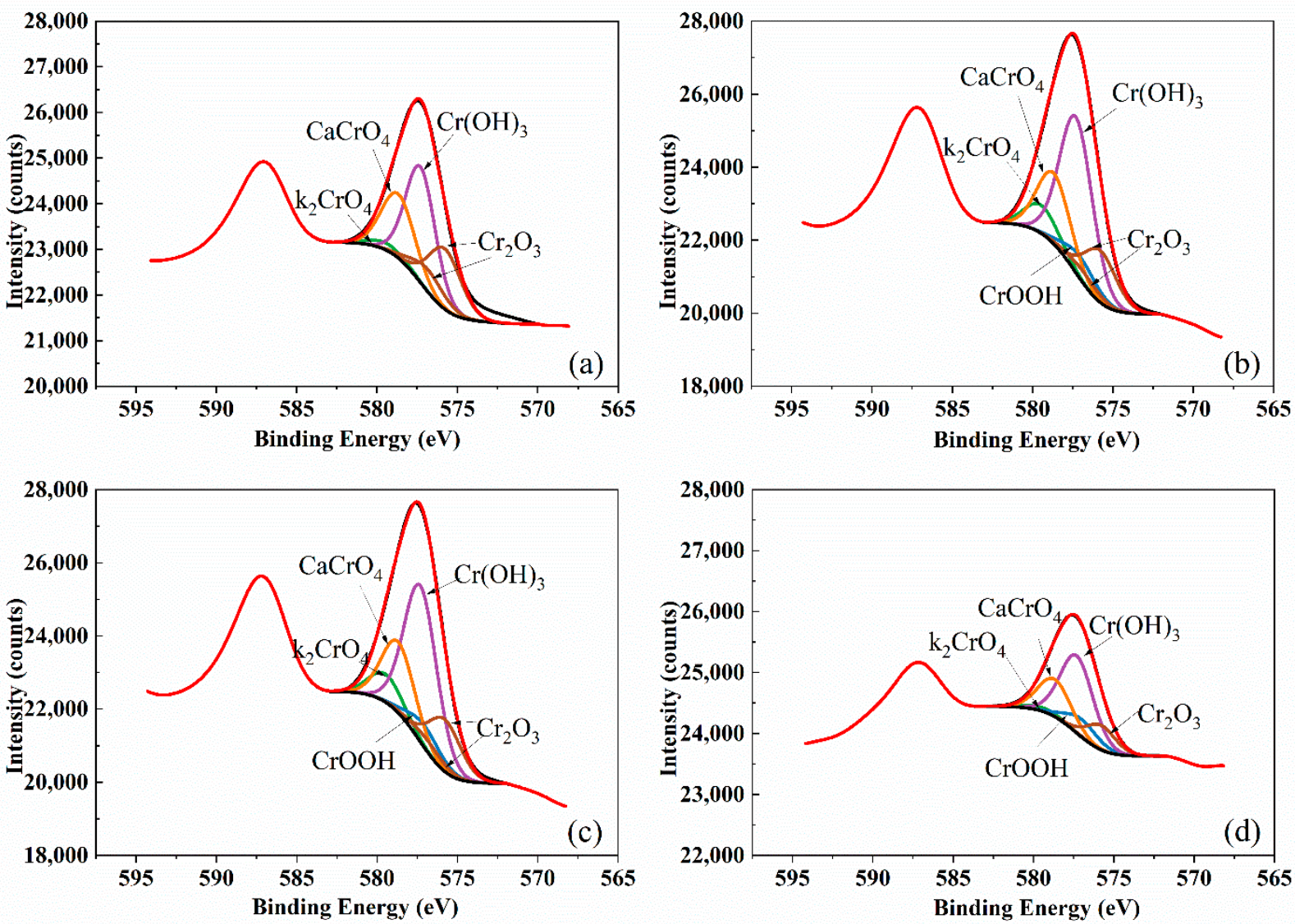

Figure 7. The X-ray photoelectron spectroscopy Cr 2p spectra of the soil samples (a) S3-1, (b) S3-6, (c) S3-7 and (d) S5-2.

As for $\mathrm{Cr}(\mathrm{VI})$, it precipitates as moderately soluble $\mathrm{CaCrO}_{4}\left(\mathrm{Ksp} 7.1 \times 10^{-4}\right)$, which was clearly identified in the XPS analysis (Figure 7) and accounted for a major proportion of the total $\mathrm{Cr}(\mathrm{VI})$. This explained the stable $\mathrm{Cr}(\mathrm{VI})$ fraction detected in the two-step sequential extraction (Figure 6). Similar results were found in naturally contaminated soils by Szecsody et al. [36], who proved the presence of $\mathrm{CaCrO}_{4}$ in the vadose zone and aquifer sediments in Hanford, Washington. In soil, $\mathrm{CaCO}_{3}$ could reduce the availability of heavy metals [80]. In this study, significant $\mathrm{CaCO}_{3}$ content was detected, as Table 1 shows. We can speculate that $\mathrm{CaCO}_{3}$ and $\mathrm{Cr}(\mathrm{VI})$ recrystallized to form $\mathrm{CaCrO}_{4}$ crystals, resulting in the immobilization of $\mathrm{Cr}(\mathrm{VI})$ in the soil [81]. These results reflect that a certain proportion of $\mathrm{Cr}(\mathrm{VI})$ existed in a relatively fixed and stable form, especially in the severely contaminated soils.

We can concluded that most of the $\mathrm{Cr}(\mathrm{VI})$ discharged from the electroplating activities was reduced to $\mathrm{Cr}(\mathrm{III})$ and fixed in the soil. Immobilization as $\mathrm{CaCrO}_{4}$ was an important fate of $\mathrm{Cr}(\mathrm{VI})$ at this actual electroplating site. However, the potential risk of pollution diffusion should not be neglected because the immobile fraction could dissolve and continuously release $\mathrm{Cr}(\mathrm{VI})$ slowly during long-term leaching activities [36]. Furthermore, this insoluble $\mathrm{CaCrO}_{4}$ is recalcitrant and difficult to treat for the same reason that $\mathrm{Cr}(\mathrm{VI})$ incorporated in the calcite is hard to contact with reducing agents [81]. Therefore, $\mathrm{CaCrO}_{4}$ precipitation was the main stable form of $\mathrm{Cr}(\mathrm{VI})$ in the soils, and more attention should be paid during the pollution remediation.

\section{Conclusions}

At this chrome plating site, the chromium distribution was associated with the electroplating processes. Soils from the chrome plating processes and the sewage tank area were contaminated by $\mathrm{Cr}(\mathrm{VI})$, with a high leaching toxicity. The coexistence of cationic 
metals ( $\mathrm{Cu}$ and $\mathrm{Zn}$ ) was also observed at some sampling points. The vertical distribution and migration of $\mathrm{Cr}(\mathrm{VI})$ were mainly affected by the soil properties, such as particle size and iron mineral content. $\mathrm{Cr}(\mathrm{VI})$ was mainly retained and reduced in the loam layer, and further accumulated in this layer reaching its maximum concentration. In the sandy loam layer, $\mathrm{Cr}(\mathrm{VI})$ reduction was limited and it was the dominant specie of $\mathrm{Cr}$. Most of the $\mathrm{Cr}$ was distributed in the non-residual fraction, and the existence of $\mathrm{Cr}(\mathrm{VI})$ resulted in a high diffusion risk for the surrounding environment. Furthermore, long-term electroplating activities can cause $\mathrm{Cr}(\mathrm{VI})$ to persist in contaminated soil because most $\mathrm{Cr}(\mathrm{VI})$ is fixed in soil via precipitation as insoluble $\mathrm{CaCrO}_{4}$. This study can provide more practical guidance for the future investigation and remediation of electroplating sites. The in situ remediation efficiency can be improved based on the distribution characteristics of $\mathrm{Cr}(\mathrm{VI})$ in contaminated sites. In contaminated calcareous soil, the formation of insoluble compounds is a significant fate of $\mathrm{Cr}(\mathrm{VI})$. Before reduction treatment, dissolving these precipitations can improve the reparation effect. Considering the diversity of electroplating activities, more actual site studies are needed to enrich our understanding.

Supplementary Materials: The following are available online at https:/ /www.mdpi.com/article/10 .3390/pr10010142/s1: Table S1, pH, $\mathrm{CaCO}_{3}$ contents, $\mathrm{I}_{\text {geo }}$ and $\mathrm{Cr}$ concentrations extracted by TCLP of soils at contaminated sampling point $\mathrm{S} 2$; Table $\mathrm{S} 2, \mathrm{pH}, \mathrm{CaCO}_{3}$ contents, $\mathrm{I}_{\text {geo }}$ and $\mathrm{Cr}$ concentrations extracted by TCLP of soils at contaminated sampling point S3; Table $\mathrm{S} 3, \mathrm{pH}, \mathrm{CaCO}_{3}$ contents, $\mathrm{I}_{\text {geo }}$ and $\mathrm{Cr}$ concentrations extracted by TCLP of soils at contaminated sampling point S5; Figure S1, X-ray diffraction (XRD) powder pattern of the three soil layers; Figure S2, The vertical distribution of copper and zinc in soils at sampling points S3 and S5.

Author Contributions: Conceptualization, J.S. (Jiacong Sun) and J.S. (Jiyan Shi); methodology, J.S. (Jiacong Sun) and Y.L.; formal analysis, J.S. (Jiacong Sun), J.Y. and C.L.; investigation, J.S. (Jiacong Sun); resources, J.S. (Jiyan Shi) and J.Y.; data curation, J.S. (Jiacong Sun); writing-original draft preparation, J.S. (Jiacong Sun); writing-review and editing, J.S. (Jiyan Shi), J.Y. and C.L.; project administration, J.S. (Jiyan Shi); funding acquisition, J.S. (Jiyan Shi). All authors have read and agreed to the published version of the manuscript.

Funding: This research was funded by the National Key Research and Development Program of China (2018YFC1802203).

Institutional Review Board Statement: Not applicable.

Informed Consent Statement: Not applicable.

Data Availability Statement: Data are contained within the article and Supplementary Materials.

Conflicts of Interest: The authors declare no conflict of interest.

\section{References}

1. Sharma, A.; Kapoor, D.; Wang, J.; Shahzad, B.; Kumar, V.; Bali, A.S.; Jasrotia, S.; Zheng, B.; Yuan, H.; Yan, D. Chromium Bioaccumulation and Its Impacts on Plants: An Overview. Plants 2020, 9, 100. [CrossRef]

2. Dhal, B.; Thatoi, H.; Das, N.; Pandey, B. Chemical and Microbial Remediation of Hexavalent Chromium from Contaminated Soil and Mining/Metallurgical Solid Waste: A Review. J. Hazard. Mater. 2013, 250-251, 272-291. [CrossRef]

3. Wang, Y.-L.; Tsou, M.-C.; Liao, H.-T.; Hseu, Z.-Y.; Dang, W.; Hsi, H.-C.; Chien, L.-C. Influence of Soil Properties on the Bioaccessibility of $\mathrm{Cr}$ and $\mathrm{Ni}$ in Geologic Serpentine and Anthropogenically Contaminated Non-Serpentine Soils in Taiwan. Sci. Total Environ. 2020, 714, 136761. [CrossRef]

4. Nguyen, Q.A.; Kim, B.; Chung, H.Y.; Nguyen, A.Q.K.; Kim, J.; Kim, K. Reductive Transformation of Hexavalent Chromium by Ferrous Ions in a Frozen Environment: Mechanism, Kinetics, and Environmental Implications. Ecotoxicol. Environ. Saf. 2021, 208, 111735. [CrossRef]

5. Wang, D.; Li, G.; Qin, S.; Tao, W.; Gong, S.; Wang, J. Remediation of Cr(VI)-Contaminated Soil Using Combined Chemical Leaching and Reduction Techniques Based on Hexavalent Chromium Speciation. Ecotoxicol. Environ. Saf. 2021, $208,111734$. [CrossRef]

6. Xu, T.; Nan, F.; Jiang, X.; Tang, Y.; Zeng, Y.; Zhang, W.; Shi, B. Effect of Soil pH on the Transport, Fractionation, and Oxidation of Chromium(III). Ecotoxicol. Environ. Saf. 2020, 195, 110459. [CrossRef]

7. Jiang, W.; Cai, Q.; Xu, W.; Yang, M.; Cai, Y.; Dionysiou, D.D.; O'Shea, K.E. Cr(VI) Adsorption and Reduction by Humic Acid Coated on Magnetite. Environ. Sci. Technol. 2014, 48, 8078-8085. [CrossRef] 
8. Zhang, X.; Gai, X.; Zhong, Z.; Bian, F.; Yang, C.; Li, Y.; Wen, X. Understanding Variations in Soil Properties and Microbial Communities in Bamboo Plantation Soils along a Chromium Pollution Gradient. Ecotoxicol. Environ. Saf. 2021, $222,112507$. [CrossRef]

9. Sharma, M.; Kumar, V.; Mahey, S.; Bhardwaj, R.; Thukral, A.K. Antagonistic Effects of EDTA Against Biochemical Toxicity Induced by $\mathrm{Cr}(\mathrm{VI})$ in Hordeum Vulgare, L. Seedlings. Physiol. Mol. Biol. Plants 2020, 26, 2487-2502. [CrossRef]

10. Zhu, F.; Liu, T.; Zhang, Z.; Liang, W. Remediation of Hexavalent Chromium in Column by Green Synthesized Nanoscale Zero-Valent Iron/Nickel: Factors, Migration Model and Numerical Simulation. Ecotoxicol. Environ. Saf. 2021, $207,111572$. [CrossRef]

11. Qin, J.; Li, Q.; Liu, Y.; Niu, A.; Lin, C. Biochar-Driven Reduction of As(V) and Cr(VI): Effects of Pyrolysis Temperature and Low-Molecular-Weight Organic Acids. Ecotoxicol. Environ. Saf. 2020, 201, 110873. [CrossRef]

12. Atlanta, G.A. Agency for Toxic Substances and Disease Registry. Asian Am. Pac. Isl. J. Health 1997, 6-10.

13. Sukumar, C.; Janaki, V.; Kamala-Kannan, S.; Shanthi, K. Biosorption of Chromium(VI) Using Bacillus Subtilis SS-1 Isolated from Soil Samples of Electroplating Industry. Clean Technol. Environ. Policy 2013, 16, 405-413. [CrossRef]

14. Zhao, L.; Ding, Z.; Sima, J.; Xu, X.; Cao, X. Development of Phosphate Rock Integrated with Iron Amendment for Simultaneous Immobilization of $\mathrm{Zn}$ and $\mathrm{Cr}(\mathrm{VI})$ in an Electroplating Contaminated Soil. Chemosphere 2017, 182, 15-21. [CrossRef]

15. Dong, X.; Li, C.; Li, J.; Wang, J.; Huang, W. A Game-Theoretic Analysis of Implementation of Cleaner Production Policies in the Chinese Electroplating Industry. Resour. Conserv. Recycl. 2010, 54, 1442-1448. [CrossRef]

16. Xiao, L.; Guan, D.; Chen, Y.; Dai, J.; Ding, W.; Peart, M.R.; Zhang, C. Distribution and Availability of Heavy Metals in Soils near Electroplating Factories. Environ. Sci. Pollut. Res. 2019, 26, 22596-22610. [CrossRef] [PubMed]

17. Luo, S.; Qin, F.; Ming, Y.; Zhao, H.; Liu, Y.; Chen, R. Fabrication Uniform Hollow Bi2S3 Nanospheres Via Kirkendall Effect for Photocatalytic Reduction of Cr(VI) in Electroplating Industry Wastewater. J. Hazard. Mater. 2017, 340, 253-262. [CrossRef]

18. Sainger, P.A.; Dhankhar, R.; Sainger, M.; Kaushik, A.; Singh, R.P. Assessment of Heavy Metal Tolerance in Native Plant Species from Soils Contaminated with Electroplating Effluent. Ecotoxicol. Environ. Saf. 2011, 74, 2284-2291. [CrossRef] [PubMed]

19. Lin, Y.; Teng, T.; Chang, T. Multivariate Analysis of Soil Heavy Metal Pollution and Landscape Pattern in Changhua County in Taiwan. Landsc. Urban Plan. 2002, 62, 19-35. [CrossRef]

20. Yan, J.L.; Quan, G.X.; Ding, C. Speciation Analysis of Heavy Metals in Electroplating Sludge and the Effect of Composting. Adv. Mater. Res. 2011, 396-398, 1975-1979.

21. Luo, Y.; Pang, J.; Li, C.; Sun, J.; Xu, Q.; Ye, J.; Wu, H.; Wan, Y.; Shi, J. Long-Term and High-Bioavailable Potentially Toxic Elements (PTEs) Strongly Influence the Microbiota in Electroplating Sites. Sci. Total Environ. 2021, 151933. [CrossRef]

22. Choppala, G.; Bolan, N.; Lamb, D.; Kunhikrishnan, A. Comparative Sorption and Mobility of Cr(III) and Cr(VI) Species in a Range of Soils: Implications to Bioavailability. Water Air Soil Pollut. 2013, 224, 1-12. [CrossRef]

23. Wang, X.; Li, L.; Yan, X.; Meng, X.; Chen, Y. Processes of Chromium (VI) Migration and Transformation in Chromate Production Site: A Case Study from the Middle of China. Chemosphere 2020, 257, 127282. [CrossRef] [PubMed]

24. Gong, Y.; Zhao, D.; Wang, Q. An Overview of Field-Scale Studies on Remediation of Soil Contaminated with Heavy Metals and Metalloids: Technical Progress over the Last Decade. Water Res. 2018, 147, 440-460. [CrossRef]

25. Hu, L.; Cai, Y.; Jiang, G. Occurrence and Speciation of Polymeric Chromium(III), Monomeric Chromium(III) and Chromium(VI) in Environmental Samples. Chemosphere 2016, 156, 14-20. [CrossRef] [PubMed]

26. Shahid, M.; Shamshad, S.; Rafiq, M.; Khalid, S.; Bibi, I.; Niazi, N.K.; Dumat, C.; Rashid, M.I. Chromium Speciation, Bioavailability, Uptake, Toxicity and Detoxification in Soil-Plant System: A Review. Chemosphere 2017, 178, 513-533. [CrossRef]

27. Agnieszka, J.; Barbara, G. Chromium, Nickel and Vanadium Mobility in Soils Derived from Fluvioglacial Sands. J. Hazard. Mater 2012, 237-238, 315-322. [CrossRef]

28. Yang, L.; Liu, G.; Di, L.; Wu, X.; You, W.; Huang, B. Occurrence, Speciation, and Risks of Trace Metals in Soils of Greenhouse Vegetable Production from the Vicinity of Industrial Areas in the Yangtze River Delta, China. Environ. Sci. Pollut. Res. 2019, 26, 8696-8708. [CrossRef]

29. Lilli, M.A.; Nikolaidis, N.P.; Karatzas, G.P.; Kalogerakis, N. Identifying the Controlling Mechanism of Geogenic Origin Chromium Release in Soils. J. Hazard. Mater. 2019, 366, 169-176. [CrossRef] [PubMed]

30. Zhang, Z.; Guo, G.; Zhao, H.; Wu, D. Partitioning, Leachability, and Speciation of Chromium in the Size-Fractions of Soil Contaminated by Chromate Production. Chemosphere 2021, 263, 128308. [CrossRef]

31. Fendorf, S.; Eick, M.J.; Grossl, P.; Sparks, D.L. Arsenate and Chromate Retention Mechanisms on Goethite. 1. Surface Structure. Environ. Sci. Technol. 1997, 31, 315-320. [CrossRef]

32. Zachara, J.M.; Ainsworth, C.C.; Brown, G.E.; Catalano, J.; McKinley, J.P.; Qafoku, O.; Smith, S.C.; Szecsody, J.E.; Traina, S.J.; Warner, J.A. Chromium Speciation and Mobility in a High Level Nuclear Waste Vadose Zone Plume. Geochim. Cosmochim. Acta 2004, 68, 13-30. [CrossRef]

33. Tian, X.; Gao, X.; Yang, F.; Lan, Y.; Mao, J.-D.; Zhou, L. Catalytic Role of Soils in the Transformation of Cr(VI) to Cr(III) in the Presence of Organic Acids Containing $\alpha-\mathrm{OH}$ Groups. Geoderma 2010, 159, 270-275. [CrossRef]

34. Zheng, Z.; Zheng, Y.; Tian, X.; Yang, Z.; Jiang, Y.; Zhao, F. Interactions between Iron Mineral-Humic Complexes and Hexavalent Chromium and the Corresponding Bio-Effects. Environ. Pollut. 2018, 241, 265-271. [CrossRef]

35. Shi, J.; McGill, W.B.; Chen, N.; Rutherford, P.M.; Whitcombe, T.W.; Zhang, W. Formation and Immobilization of Cr(VI) Species in Long-Term Tannery Waste Contaminated Soils. Environ. Sci. Technol. 2020, 54, 7226-7235. [CrossRef] [PubMed] 
36. Szecsody, J.E.; Truex, M.J.; Qafoku, N.P.; McKinley, J.P.; Ivarson, K.A.; Di Pietro, S. Persistence of Chromate in Vadose Zone and Aquifer Sediments in Hanford, Washington. Sci. Total Environ. 2019, 676, 482-492. [CrossRef]

37. Chrysochoou, M.; Ferreira, D.R.; Johnston, C.P. Calcium Polysulfide Treatment of Cr(VI)-contaminated soil. J. Hazard. Mater. 2010, 179, 650-657. [CrossRef]

38. Kirichenko, K.Y.; Vakhniuk, I.A.; Ivanov, V.V.; Tarasenko, I.A.; Kosyanov, D.Y.; Medvedev, S.A.; Soparev, V.P.; Drozd, V.A.; Kholodov, A.S.; Golokhvast, K.S. Complex Study of Air Pollution in Electroplating Workshop. Sci. Rep. 2020, 10, 1-14. [CrossRef]

39. Fandeur, D.; Juillot, F.; Morin, G.; Olivi, L.; Cognigni, A.; Webb, S.M.; Ambrosi, J.P.; Fritsch, E.; Guyot, F.; Brown, G.E., Jr. XANES Evidence for Oxidation of $\mathrm{Cr}(\mathrm{III})$ to $\mathrm{Cr}(\mathrm{VI})$ by Mn Oxides in a Lateritic Regolith Developed on Serpentinized Ultramafic Rocks of New Caledonia. Environ. Sci. Technol. 2009, 43, 7384-7390. [CrossRef]

40. Xu, Q.; Gao, Y.; Wu, X.; Ye, J.; Ren, X.; Zhou, Z.; Cai, Q.; Wu, H.; Pang, J.; Luo, Y.; et al. Derivation of Empirical Model to Predict the Accumulation of $\mathrm{Pb}$ in Rice Grain. Environ. Pollut. 2021, 274, 116599. [CrossRef]

41. Tessier, A.; Campbell, P.G.C.; Bisson, M. Sequential Extraction Procedure for the Speciation of Particulate Trace Metals. Anal. Chem. 1979, 51, 844-851. [CrossRef]

42. Choppala, G.; Kunhikrishnan, A.; Seshadri, B.; Park, J.H.; Bush, R.; Bolan, N. Comparative Sorption of Chromium Species as Influenced by pH, Surface Charge and Organic Matter Content in Contaminated Soils. J. Geochem. Explor. 2018, 184, 255-260. [CrossRef]

43. Adimalla, N.; Qian, H.; Nandan, M.; Hursthouse, A. Potentially Toxic Elements (PTEs) Pollution in Surface Soils in a Typical Urban Region of South India: An Application of Health Risk Assessment and Distribution Pattern. Ecotoxicol. Environ. Saf. 2020, 203, 111055. [CrossRef] [PubMed]

44. Negahban, S.; Mokarram, M.; Pourghasemi, H.R.; Zhang, H. Ecological Risk Potential Assessment of Heavy Metal Contaminated Soils in Ophiolitic Formations. Environ. Res. 2021, 192, 110305. [CrossRef]

45. Muller, G. Index of Geo-Accumulation in Sediments of the Rhine River. Geo J. 1969, 2, 108-118.

46. CNEMS. Element Background Values of Soils in China; China Environmental Sciences Press: Beijing, China, 1990; pp. 87-496.

47. Del Pianta, D.; Frayret, J.; Gleyzes, C.; Cugnet, C.; Dupin, J.C.; Le Hecho, I. Determination of the Chromium(III) Reduction Mechanism During Chromium Electroplating. Electrochim. Acta 2018, 284, 234-241. [CrossRef]

48. State Environmental Protection Administration of China (SEPAC). The Soil Environmental Quality Risk Control Standard for Soil Contamination of Development Land (GB36600-2018). 2018. Available online: http://www.mee.gov.cn/ywgz/fgbz/bz/bzwb/ trhj/201807/t20180703_446027.shtml. (accessed on 1 January 2022).

49. Jagupilla, S.C.; Moon, D.H.; Wazne, M.; Christodoulatos, C.; Kim, M.-G. Effects of Particle Size and Acid Addition on the Remediation of Chromite Ore Processing Residue Using Ferrous Sulfate. J. Hazard. Mater. 2009, 168, 121-128. [CrossRef]

50. Graham, M.C.; Farmer, J.G.; Anderson, P.; Paterson, E.; Hillier, S.; Lumsdon, D.G.; Bewley, R.J. Calcium Polysulfide Remediation of Hexavalent Chromium Contamination from Chromite Ore Processing Residue. Sci. Total Environ. 2006, 364, 32-44. [CrossRef] [PubMed]

51. Shi, J.; Chen, H.; Arocena, J.M.; Whitcombe, T.; Thring, R.W.; Memiaghe, J.N. Elemental Sulfur Amendment Decreases BioAvailable Cr-VI in Soils Impacted by Leather Tanneries. Environ. Pollut. 2016, 212, 57-64. [CrossRef]

52. Pohlandt-Schwandt, K. Treatment of Wood Ash Containing Soluble Chromate. Biomass Bioenergy 1999, 16, 447-462. [CrossRef]

53. Kalra, Y.P.; Maynard, D.G. Methods Manual for Forest Soil and Plant Analysis; Canadian Forest Service Publications: Edmonton, AB, Canada, 1991; Volume 319.

54. Wu, X.; Cai, Q.; Xu, Q.; Zhou, Z.; Shi, J. Wheat (Triticum aestivum L.) Grains Uptake of Lead (Pb), Transfer Factors and Prediction Models for Various Types of Soils from China. Ecotoxicol. Environ. Saf. 2020, 206, 111387. [CrossRef] [PubMed]

55. He, Y.T.; Traina, S.J. Cr(VI) Reduction and Immobilization by Magnetite under Alkaline pH Conditions: The Role of Passivation. Environ. Sci. Technol. 2005, 39, 4499-4504. [CrossRef] [PubMed]

56. Bedbabis, S.; Ben Rouina, B.; Boukhris, M.; Ferrara, G. Effect of Irrigation with Treated Wastewater on Soil Chemical Properties and Infiltration Rate. J. Environ. Manag. 2014, 133, 45-50. [CrossRef] [PubMed]

57. Ertani, A.; Mietto, A.; Borin, M.; Nardi, S. Chromium in Agricultural Soils and Crops: A Review. Water Air Soil Pollut. 2017, 228, 190. [CrossRef]

58. maNeill, L.; McLean, J.; Parks, J.; Edwards, M. Hexavalent Chromium Review, part 2: Chemistry, Occurrence, and Treatment. J. Am. Water Works. 2012, 104, 39-40. [CrossRef]

59. Sun, Z.; Xie, X.; Wang, P.; Hu, Y.; Cheng, H. Heavy Metal Pollution Caused by Small-Scale Metal Ore Mining Activities: A Case Study from a Polymetallic Mine in South China. Sci. Total Environ. 2018, 639, 217-227. [CrossRef]

60. Li, S.; Zhao, B.; Jin, M.; Hu, L.; Zhong, H.; He, Z. A Comprehensive Survey on the Horizontal and Vertical Distribution of Heavy Metals and Microorganisms in Soils of a Pb/Zn Smelter. J. Hazard. Mater. 2020, 400, 123255. [CrossRef]

61. Shaheen, S.; Rinklebe, J. Geochemical Fractions of Chromium, Copper, and Zinc and Their Vertical Distribution in Floodplain Soil Profiles along the Central Elbe River, Germany. Geoderma 2014, 228-229, 142-159. [CrossRef]

62. Tengsuwan, S.; Ohshima, M. Environmentally Benign Electroless Nickel Plating Using Supercritical Carbon-Dioxide on Hydrophilically Modified Acrylonitrile-Butadiene-Styrene. Appl. Surf. Sci. 2014, 311, 189-200. [CrossRef]

63. Schlesinger, M.; Paunovic, M. Modern Electroplating; John Wiley \& Sons: Hoboken, NJ, USA, 2011; Volume 55.

64. Young, G.; Chen, Y.; Yang, M. Concentrations, Distribution, and Risk Assessment of Heavy Metals in the Iron Tailings of Yeshan National Mine Park in Nanjing, China. Chemosphere 2021, 271, 129546. [CrossRef] 
65. Fonseca, B.; Maio, H.; Quintelas, C.; Teixeira, A.S.; Tavares, T. Retention of $\mathrm{Cr}(\mathrm{VI})$ and Pb(II) on a Loamy Sand Soil: Kinetics, Equilibria and Breakthrough. Chem. Eng. J. 2009, 152, 212-219. [CrossRef]

66. Rajmohan, N.; Prathapar, S.A.; Jayaprakash, M.; Nagarajan, R. Vertical Distribution of Heavy Metals in Soil Profile in a Seasonally Waterlogging Agriculture Field in Eastern Ganges Basin. Environ. Monit. Assess. 2014, 186, 5411-5427. [CrossRef]

67. Wang, Y.; Zeng, X.; Lu, Y.; Su, S.; Bai, L.; Li, L.; Wu, C. Effect of Aging on the Bioavailability and Fractionation of Arsenic in Soils Derived From Five Parent Materials in a Red Soil Region of Southern China. Environ. Pollut. 2015, 207, 79-87. [CrossRef]

68. Liu, G.; Wang, J.; Liu, X.; Liu, X.; Li, X.; Ren, Y.; Wang, J.; Dong, L. Partitioning and Geochemical Fractions of Heavy Metals from Geogenic and Anthropogenic Sources in Various Soil Particle Size Fractions. Geoderma 2018, 312, 104-113. [CrossRef]

69. Bishop, M.E.; Dong, H.; Glasser, P.; Briggs, B.; Pentrak, M.; Stucki, J.W.; Boyanov, M.I.; Kemner, K.M.; Kovarik, L. Reactivity of Redox Cycled Fe-Bearing Subsurface Sediments Towards Hexavalent Chromium Reduction. Geochim. Cosmochim. Acta 2019, 252, 88-106. [CrossRef]

70. Zhu, J.; Huang, Q.; Pigna, M.; Violante, A. Competitive Sorption of $\mathrm{Cu}$ and $\mathrm{Cr}$ on Goethite and Goethite-Bacteria Complex. Chem. Eng. J. 2012, 179, 26-32. [CrossRef]

71. Zheng, C.; Wu, Q.; Hu, X.; Wang, Y.; Chen, Y.; Zhang, S.; Zheng, H. Adsorption Behavior of Heavy Metal Ions on a PolymerImmobilized Amphoteric Biosorbent: Surface Interaction Assessment. J. Hazard. Mater. 2021, 403, 123801. [CrossRef]

72. He, K.; Sun, Z.; Hu, Y.; Zeng, X.; Yu, Z.; Cheng, H. Comparison of Soil Heavy Metal Pollution Caused by e-Waste Recycling Activities and Traditional Industrial Operations. Environ. Sci. Pollut. Res. 2017, 24, 9387-9398. [CrossRef] [PubMed]

73. Xie, X.; Min, X.; Chai, L.; Tang, C.; Liang, Y.; Li, M.; Ke, Y.; Chen, J.; Wang, Y. Quantitative Evaluation of Environmental Risks of Flotation Tailings from Hydrothermal Sulfidation-Flotation Process. Environ. Sci. Pollut. Res. 2013, 20, 6050-6058. [CrossRef]

74. Sharma, M.; Kumar, V.; Bhardwaj, R.; Thukral, A.K. Tartaric Acid Mediated Cr Hyperaccumulation and Biochemical Alterations in Seedlings of Hordeum vulgare L. J. Plant Growth Regul. 2019, 39, 1-14. [CrossRef]

75. Szulczewski, M.D.; Helmke, P.A.; Bleam, W.F. Comparison of XANES Analyses and Extractions To Determine Chromium Speciation in Contaminated Soils. Environ. Sci. Technol. 1997, 31, 2954-2959. [CrossRef]

76. Kunene, S.C.; Lin, K.S.; Mdlovu, N.V.; Lin, Y.-S.; Mdlovu, N.B. Speciation and Fate of Toxic Cadmium in Contaminated Paddy Soils and Rice Using XANES/EXAFS Spectroscopy. J. Hazard. Mater. 2020, 383, 121167. [CrossRef]

77. Jardine, P.M.; McCarthy, J.F.; Weber, N.L. Mechanisms of Dissolved Organic Carbon Adsorption on Soil. Soil Sci. Soc. Am. J. 1989, 53, 1378-1385. [CrossRef]

78. Banks, M.; Schwab, A.; Henderson, C. Leaching and Reduction of Chromium in Soil as Affected by Soil Organic Content and Plants. Chemosphere 2006, 62, 255-264. [CrossRef] [PubMed]

79. Zhao, X.; Sobecky, P.A.; Zhao, L.; Crawford, P.; Li, M. Chromium(VI) Transport and Fate in Unsaturated Zone and Aquifer: 3D Sandbox results. J. Hazard. Mater. 2016, 306, 203-209. [CrossRef]

80. Romero-Freire, A.; Peinado, F.M.; van Gestel, K. Effect of Soil Properties on the Toxicity of Pb: Assessment of the Appropriateness of Guideline Values. J. Hazard. Mater. 2015, 289, 46-53. [CrossRef]

81. Tang, Y.; Elzinga, E.J.; Lee, Y.J.; Reeder, R.J. Coprecipitation of Chromate with Calcite: Batch Experiments and X-ray Absorption Spectroscopy. Geochim. Cosmochim. Acta 2007, 71, 1480-1493. [CrossRef] 